\title{
1. SEDIMENTOLOGICAL AND STABLE ISOTOPE CHANGES AT THE MESSINIAN/PLIOCENE BOUNDARY IN THE EASTERN MEDITERRANEAN (HOLES 968A, 969A, AND 969B) ${ }^{1}$
}

\author{
Catherine Pierre, ${ }^{2}$ Jean-Marie Rouchy, ${ }^{3}$ and Marie-Madeleine Blanc-Valleron ${ }^{3}$
}

\begin{abstract}
The Messinian/Pliocene boundary was continuously cored in the Eastern Mediterranean at Hole 968A on the northern flank of the Eratosthenes seamount and at Holes 969A and 969B on the Mediterranean Ridge. It is marked by major changes of lithology, carbonate content, and stable isotope composition of mixed carbonate-siliciclastic sediments, which record a sharp modification of the hydric balance of the Mediterranean. During the terminal Messinian, after the salinity crisis, huge freshwater dilution created brackish conditions of variable level of concentration in the deep shallow-water Mediterranean basins. In a period that probably lasted $\sim 1000-2000 \mathrm{yr}$, the entire Mediterranean was refilled by marine waters at the onset of the early Pliocene so that homogeneous open-sea conditions were established in the different basins.
\end{abstract}

\section{INTRODUCTION}

The Messinian/Pliocene boundary is expressed differently in the Mediterranean sub-basins. In the marginal areas that are now outcropping in Spain, Italy, Cyprus, and North Africa, it is often marked by a sedimentary unconformity (erosional surface, gap in the sedimentation, paleosoils, change to continental sedimentary deposition during early Pliocene; Cita et al., 1978; Rouchy, 1982; Pierre and Rouchy, 1990). In the deepest parts of the Mediterranean, the Messinian/Pliocene boundary was drilled during Deep Sea Drilling Project (DSDP) and Ocean Drilling Program (ODP) cruises at Sites 132, 652, 653, and 654 in the Tyrrhenian Basin, Sites 371 and 372 in the Balearic Basin, Sites 125 and 374 in the Ionian Basin, Sites 375 and 376 in the Levantine Basin, and Site 378 in the Cretan Basin. Everywhere, a sharp lithologic change characterizes this transition, indicating that major paleoenvironmental modifications occurred in the whole Mediterranean.

The Messinian/Pliocene boundary was cored during ODP Leg 160 at Site 968 on the Cyprus lower slope and at Site 969 on the Mediterranean Ridge (Fig. 1). A high-resolution sampling scheme (samples taken every $5 \mathrm{~cm}$ ) was employed to investigate the sedimentological and isotopic records of the major hydrological event in the Eastern Mediterranean, which ended the hypersaline regime of Messinian times and preceded the return to open-sea conditions at the onset of the Pliocene.

At both sites, the sedimentation rates during the early Pliocene are high $(80 \mathrm{~m} / \mathrm{m}$.y. at Site $968,86 \mathrm{~m} / \mathrm{m}$.y. at Site 969$)$; the 5 -cm interval thus represents an average time interval of $\sim 600 \mathrm{yr}$. However, the sedimentation rate estimations were not possible for the late Messinian, where biostratigraphic markers are lacking (Shipboard Scientific Party, 1996a, 1996b).

\section{METHODS}

The carbonate content of each sample was measured on $100 \mathrm{mg}$ of powdered sediment using a manocalcimeter. X-ray diffraction

${ }^{1}$ Robertson, A.H.F., Emeis, K.-C., Richter, C., and Camerlenghi, A. (Eds.), 1998. Proc. ODP, Sci. Results, 160: College Station, TX (Ocean Drilling Program).

${ }^{2}$ UMR 121, CNRS-Université-ORSTOM, Laboratoire d'Océanographie Dynamique et de Climatologie, Université Pierre et Marie Curie, 4 Place Jussieu, 75252 Paris Cedex 05, France.cat@lodyc.jussieu.fr

${ }^{3}$ URA 1761, Laboratoire de Géologie, Muséum National d'Histoire Naturelle, 43 rue Buffon, 75005 Paris, France.
(XRD) analyses were performed on bulk samples using a Siemens D500 instrument $(\mathrm{Cu} \mathrm{K \alpha}, \mathrm{Ni}$ filtered, radiation). Calcite and dolomite weight percentages were estimated using peak heights and manocalcimeter values (Tables 1, 2, 3). The mineralogy of the carbonate fraction was systematically determined by XRD to quantify the calcite:dolomite ratio and to characterize the composition of the different mineral phases by measuring the precise position of the $d_{104}$ peak. Most of the samples were observed with smear slides under the optical microscope, and some of them were selected for examination by scanning electron microscope (SEM).

The oxygen and carbon isotope compositions were measured on the bulk carbonate fraction, which contains dolomite as a trace component and cannot contribute significantly to the isotopic signal. The sediment samples were digested in $100 \%$ orthophosphoric acid at $25^{\circ} \mathrm{C}$ (McCrea, 1950), and the resulting $\mathrm{CO}_{2}$ gas was analyzed using a VG-SIRA 9 Triple Collector Mass Spectrometer in LODYC. The isotopic compositions are expressed by the conventional $\delta$ notation relative to the Peedee belemnite (PDB) reference (Craig, 1957):

$$
\begin{aligned}
& \delta^{18} \mathrm{O} \text { sample } \% o=1000 \times\left({ }^{18} \mathrm{O} /{ }^{16} \mathrm{O} \text { sample }-{ }^{18} \mathrm{O} /{ }^{16} \mathrm{O} \text { reference }\right) / \\
& { }^{18} \mathrm{O} /{ }^{16} \mathrm{O} \text { reference, and } \\
& \delta^{13} \mathrm{C} \text { sample } \% o=1000 \times\left({ }^{13} \mathrm{C} /{ }^{12} \mathrm{C} \text { sample }-{ }^{13} \mathrm{C} /{ }^{12} \mathrm{C} \text { reference }\right) / \\
& { }^{13} \mathrm{C} /{ }^{12} \mathrm{C} \text { reference. }
\end{aligned}
$$

The analytical precision is $0.01 \%$ ofor both $\delta^{18} \mathrm{O}$ and $\delta^{13} \mathrm{C}$ values; the reproducibility of the carbonate standard run on separate days is $\pm 0.05 \%$ o for $\delta^{18} \mathrm{O}$ and $\pm 0.02 \%$ o for $\delta^{13} \mathrm{C}$.

\section{SEDIMENTOLOGY}

\section{Results}

\section{Site 968}

Hole 968A was drilled at a water depth of $1961 \mathrm{~m}$, on the Cyprus lower slope, and penetrated $302.7 \mathrm{~m}$ of sediments.

The Miocene/Pliocene boundary is marked at $153.80 \mathrm{~m}$ below seafloor (mbsf; Sample 160-968A-17X-2, $10 \mathrm{~cm}$ ) by a net lithologic transition from light to dark brown calcareous clays and silty clays with reworked coccoliths to gray bioturbated nannofossil ooze with foraminifers characteristic of the early Pliocene MPL2 zone (Shipboard Scientific Party, 1996a). Below about 190 mbsf the sediments contain a typical Lago Mare faunal association with Cyprideis pan-

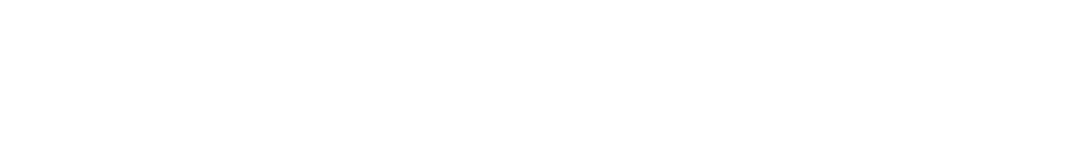


Figure 1. Location map of Sites 968 and 969 in the Eastern Mediterranean.

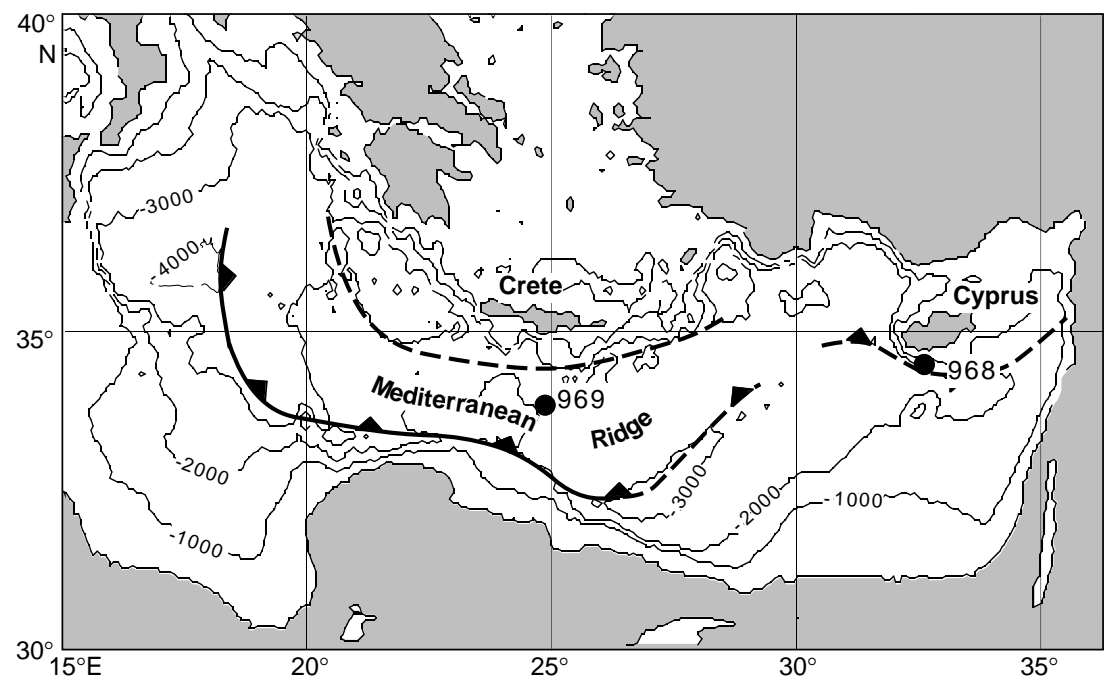

nonica and Ammonia tepida. These deposits including the gypsumrich intercalations from 211.0 to $219.7 \mathrm{mbsf}$ (Core 25X), are considered time equivalents to the terminal Messinian (Shipboard Scientific Party, 1996a).

The carbonate content of the sediment changes abruptly at the Messinian/Pliocene transition from average values of $22 \%$ in the upper Messinian to $58 \%$ in the lower Pliocene (Table 1; see Fig. 2). This difference results from a sharp increase in the amount of calcite above the Messinian/Pliocene boundary (153.775 mbsf), whereas the dolomite content remains very low ( 2\%; see Table 1$)$. This calcite corresponds mainly to nannofossils (Pl. 1, Fig. 4). Two samples located above the transition display a dolomite content $3.1 \%$ and $2.6 \%$ ) similar to that of the underlying Messinian deposits. The dolomite, commonly associated with detrital silicate minerals, probably corresponds to a detrital component (Shipboard Scientific Party, 1996a).

The composition of calcites is relatively homogeneous, although the Messinian calcites are low-Mg to near stoichiometry $\left(3.030<\mathrm{d}_{104}\right.$ $\AA<3.034$ ), whereas the Pliocene calcites are closer to stoichiometry $\left(3.033<\mathrm{d}_{104} \AA<3.035\right)$. The values of $\mathrm{d}_{104}$ of dolomite are also relatively homogeneous whatever the age of the deposits and are characteristic of Ca-rich dolomite compositions $\left(2.894<\mathrm{d}_{104} \AA<2.902\right)$. One sample shows a mixture of stoichiometric and Ca-rich dolomite phases.

The carbonate fraction of the Messinian sediments is usually composed of fine grains ranging in size from 5 to $20 \mu \mathrm{m}$. At least four main components occurring in variable proportions can be recognized:

1. The biogenic carbonates, mostly calcareous nannoplankton, represent a few percent to $\sim 25 \%$ of the bulk carbonate fraction. These components may be reworked and comprise various species of coccoliths (sometimes grouped in coccospheres), fragmented discoasters, and rare specimens of Thoracosphaera sp.

2. Elongated subhedral calcite grains (netting needle-like) of 6$15 \mu \mathrm{m}$ in length are present (Pl. 1, Fig. 6). In the lower part of the series, a few white millimeter-thick laminae intercalated within the more silty sediment are almost exclusively composed of such crystalline facies (Shipboard Scientific Party, 1996a).

3. Euhedral rhombohedral crystals, ascribed to dolomite are present, with a size ranging from a few micrometers to $20 \mu \mathrm{m}$ (Pl. 1, Fig. 5).

4. Various undifferentiated carbonate debris are present.
Table 1. Carbonate mineral composition and $\delta^{18} \mathrm{O}$ and $\delta^{13} \mathrm{C}$ values of the bulk carbonate fraction of the sediments at Hole 968A.

\begin{tabular}{|c|c|c|c|c|c|c|}
\hline $\begin{array}{l}\text { Core, section, } \\
\text { interval }(\mathrm{cm})\end{array}$ & $\begin{array}{l}\text { Depth } \\
\text { (mbsf) }\end{array}$ & $\begin{array}{c}\text { Total } \\
\text { carbonates } \\
(\mathrm{wt} \%)\end{array}$ & $\begin{array}{l}\text { Calcite } \\
(w t \%)\end{array}$ & $\begin{array}{l}\text { Dolomite } \\
\text { (wt } \%)\end{array}$ & $\begin{array}{c}\delta^{18} \mathrm{O}^{*} \\
(\% o)\end{array}$ & $\begin{array}{c}\delta^{13} \mathrm{C}^{*} \\
(\% \circ)\end{array}$ \\
\hline \multicolumn{7}{|l|}{ 160-968A- } \\
\hline $17 X-1,65-66$ & 152.85 & 59 & 57 & 2 & 1.50 & 1.07 \\
\hline $17 X-1,70-71$ & 152.90 & 62 & 60 & 2 & 1.39 & 1.11 \\
\hline $17 X-1,75-76$ & 152.95 & 59 & 57 & 2 & 1.59 & 1.11 \\
\hline $17 \mathrm{X}-1,80-81$ & 153.00 & 59 & 58 & 1 & 1.40 & 1.12 \\
\hline $17 X-1,85-86$ & 153.05 & 49 & 48 & 1 & 1.28 & 0.82 \\
\hline $17 X-1,90-91$ & 153.10 & 60 & 59 & 1 & 1.02 & 0.83 \\
\hline $17 X-1,95-96$ & 153.15 & 63 & 62 & 1 & 1.33 & 1.10 \\
\hline $17 \mathrm{X}-1,100-101$ & 153.20 & 59 & 58 & 1 & 1.46 & 1.00 \\
\hline $17 \mathrm{X}-1,105-106$ & 153.25 & 39 & 38 & 1 & 0.52 & 0.57 \\
\hline $17 X-1,110-111$ & 153.30 & 64 & 63 & 1 & 1.37 & 1.14 \\
\hline $17 \mathrm{X}-1,115-116$ & 153.35 & 56 & 55 & 1 & 1.27 & 1.21 \\
\hline $17 \mathrm{X}-1,120-121$ & 153.40 & 49 & 48 & 1 & 0.73 & 0.66 \\
\hline $17 \mathrm{X}-1,125-126$ & 153.45 & 62 & 61 & 1 & 1.37 & 0.93 \\
\hline $17 \mathrm{X}-1,130-131$ & 153.50 & 64 & 63 & 1 & 1.53 & 0.93 \\
\hline $17 \mathrm{X}-1,135-136$ & 153.55 & 63 & 61 & 2 & 1.47 & 1.00 \\
\hline $17 \mathrm{X}-1,140-141$ & 153.60 & 63 & 61 & 2 & 1.42 & 0.97 \\
\hline $17 \mathrm{X}-1,145-146$ & 153.65 & 58 & 57 & 1 & 1.17 & 0.78 \\
\hline $17 X-1,149-150$ & 153.69 & 59 & 58 & 1 & 1.40 & 1.00 \\
\hline $17 \mathrm{X}-2,0-1$ & 153.70 & 54 & 53 & 1 & 1.25 & 0.88 \\
\hline $17 X-2,5-6$ & 153.75 & 68 & 65 & 3 & 0.96 & 0.54 \\
\hline $17 X-2,10-11$ & 153.80 & 48 & 45 & 3 & -1.37 & -1.34 \\
\hline $17 X-2,15-16$ & 153.85 & 20 & 17 & 3 & -2.96 & -3.31 \\
\hline $17 X-2,20-21$ & 153.90 & 21 & 18 & 3 & -3.63 & -3.69 \\
\hline $17 X-2,25-26$ & 153.95 & 21 & 18 & 3 & -2.78 & -3.32 \\
\hline $17 X-2,30-31$ & 154.00 & 20 & 19 & 1 & -2.89 & -3.12 \\
\hline $17 X-2,35-36$ & 154.05 & 21 & 19 & 2 & -2.67 & -3.3 \\
\hline $17 X-2,40-41$ & 154.10 & 23 & 20 & 3 & -3.10 & -3.35 \\
\hline $17 X-2,45-46$ & 154.15 & 23 & 20 & 3 & -3.25 & -3.42 \\
\hline $17 X-2,50-51$ & 154.20 & 20 & 18 & 2 & -3.06 & -3.45 \\
\hline $17 X-2,55-56$ & 154.25 & 21 & 19 & 2 & -3.08 & -3.35 \\
\hline $17 X-2,60-61$ & 154.30 & 20 & 18 & 2 & -3.42 & -3.45 \\
\hline $17 X-2,65-66$ & 154.35 & 22 & 19 & 3 & -3.22 & -3.47 \\
\hline $17 X-2,70-71$ & 154.40 & 20 & 17 & 3 & -3.16 & -3.55 \\
\hline $17 X-2,75-76$ & 154.45 & 24 & 22 & 2 & -2.29 & -2.62 \\
\hline $17 \mathrm{X}-2,80-81$ & 154.50 & 19 & 17 & 2 & -3.37 & -3.58 \\
\hline $17 X-2,85-86$ & 154.55 & 25 & 23 & 2 & -2.83 & -2.72 \\
\hline $17 X-2,90-91$ & 154.60 & 24 & 22 & 2 & -2.67 & -2.9 \\
\hline $17 X-2,95-96$ & 154.65 & 21 & 20 & 1 & -2.25 & -2.53 \\
\hline $17 X-2,100-101$ & 154.70 & 25 & 23 & 2 & -2.66 & -2.82 \\
\hline $17 \mathrm{X}-2,105-106$ & 154.75 & 23 & 20 & 3 & -3.08 & -3.47 \\
\hline $17 \mathrm{X}-2,110-111$ & 154.80 & 23 & 21 & 2 & -2.95 & -3.72 \\
\hline $17 X-2,115-116$ & 154.85 & 25 & 23 & 2 & -2.69 & -3.09 \\
\hline
\end{tabular}

Note: $*=$ PDB bulk carbonate.

The Pliocene sediments are characterized by greater amounts of biogenic carbonates, mostly composed of calcareous nannoplankton, associated with rare euhedral crystals of dolomite and carbonate fragments. The netting needle-like calcite is not more common in the early Pliocene deposits. 
Table 2. Carbonate mineral composition and $\delta^{18} \mathrm{O}$ and $\delta^{13} \mathrm{C}$ values of the bulk carbonate fraction of the sediments at Hole 969B.

\begin{tabular}{|c|c|c|c|c|c|c|}
\hline $\begin{array}{l}\text { Core, section, } \\
\text { interval }(\mathrm{cm})\end{array}$ & $\begin{array}{l}\text { Depth } \\
\text { (mbsf) }\end{array}$ & $\begin{array}{c}\text { Total } \\
\text { carbonates } \\
(\mathrm{wt} \%)\end{array}$ & $\begin{array}{c}\text { Calcite } \\
\text { (wt\%) }\end{array}$ & $\begin{array}{l}\text { Dolomite } \\
\text { (wt } \%)\end{array}$ & $\begin{array}{c}\delta^{18} \mathrm{O}^{*} \\
(\% o)\end{array}$ & $\begin{array}{c}\delta^{13} C^{*} \\
(\% \circ)\end{array}$ \\
\hline \multicolumn{7}{|l|}{ 160-968A- } \\
\hline $17 X-1,65-66$ & 152.85 & 59 & 57 & 2 & 1.50 & 1.07 \\
\hline $17 X-1,70-71$ & 152.90 & 62 & 60 & 2 & 1.39 & 1.11 \\
\hline $17 X-1,75-76$ & 152.95 & 59 & 57 & 2 & 1.59 & 1.11 \\
\hline $17 X-1,80-81$ & 153.00 & 59 & 58 & 1 & 1.40 & 1.12 \\
\hline $17 X-1,85-86$ & 153.05 & 49 & 48 & 1 & 1.28 & 0.82 \\
\hline $17 X-1,90-91$ & 153.10 & 60 & 59 & 1 & 1.02 & 0.83 \\
\hline $17 \mathrm{X}-1,95-96$ & 153.15 & 63 & 62 & 1 & 1.33 & 1.10 \\
\hline $17 \mathrm{X}-1,100-101$ & 153.20 & 59 & 58 & 1 & 1.46 & 1.00 \\
\hline $17 \mathrm{X}-1,105-106$ & 153.25 & 39 & 38 & 1 & 0.52 & 0.57 \\
\hline $17 \mathrm{X}-1,110-111$ & 153.30 & 64 & 63 & 1 & 1.37 & 1.14 \\
\hline $17 X-1,115-116$ & 153.35 & 56 & 55 & 1 & 1.27 & 1.21 \\
\hline $17 \mathrm{X}-1,120-121$ & 153.40 & 49 & 48 & 1 & 0.73 & 0.66 \\
\hline $17 \mathrm{X}-1,125-126$ & 153.45 & 62 & 61 & 1 & 1.37 & 0.93 \\
\hline $17 \mathrm{X}-1,130-131$ & 153.50 & 64 & 63 & 1 & 1.53 & 0.93 \\
\hline $17 \mathrm{X}-1,135-136$ & 153.55 & 63 & 61 & 2 & 1.47 & 1.00 \\
\hline $17 \mathrm{X}-1,140-141$ & 153.60 & 63 & 61 & 2 & 1.42 & 0.97 \\
\hline $17 \mathrm{X}-1,145-146$ & 153.65 & 58 & 57 & 1 & 1.17 & 0.78 \\
\hline $17 \mathrm{X}-1,149-150$ & 153.69 & 59 & 58 & 1 & 1.40 & 1.00 \\
\hline $17 \mathrm{X}-2,0-1$ & 153.70 & 54 & 53 & 1 & 1.25 & 0.88 \\
\hline $17 X-2,5-6$ & 153.75 & 68 & 65 & 3 & 0.96 & 0.54 \\
\hline $17 X-2,10-11$ & 153.80 & 48 & 45 & 3 & -1.37 & -1.34 \\
\hline $17 X-2,15-16$ & 153.85 & 20 & 17 & 3 & -2.96 & -3.31 \\
\hline $17 X-2,20-21$ & 153.90 & 21 & 18 & 3 & -3.63 & -3.69 \\
\hline $17 X-2,25-26$ & 153.95 & 21 & 18 & 3 & -2.78 & -3.32 \\
\hline $17 X-2,30-31$ & 154.00 & 20 & 19 & 1 & -2.89 & -3.12 \\
\hline $17 X-2,35-36$ & 154.05 & 21 & 19 & 2 & -2.67 & -3.3 \\
\hline $17 X-2,40-41$ & 154.10 & 23 & 20 & 3 & -3.10 & -3.35 \\
\hline $17 X-2,45-46$ & 154.15 & 23 & 20 & 3 & -3.25 & -3.42 \\
\hline $17 \mathrm{X}-2,50-51$ & 154.20 & 20 & 18 & 2 & -3.06 & -3.45 \\
\hline $17 X-2,55-56$ & 154.25 & 21 & 19 & 2 & -3.08 & -3.35 \\
\hline $17 X-2,60-61$ & 154.30 & 20 & 18 & 2 & -3.42 & -3.45 \\
\hline $17 X-2,65-66$ & 154.35 & 22 & 19 & 3 & -3.22 & -3.47 \\
\hline $17 X-2,70-71$ & 154.40 & 20 & 17 & 3 & -3.16 & -3.55 \\
\hline $17 X-2,75-76$ & 154.45 & 24 & 22 & 2 & -2.29 & -2.62 \\
\hline $17 X-2,80-81$ & 154.50 & 19 & 17 & 2 & -3.37 & -3.58 \\
\hline $17 X-2,85-86$ & 154.55 & 25 & 23 & 2 & -2.83 & -2.72 \\
\hline $17 \mathrm{X}-2,90-91$ & 154.60 & 24 & 22 & 2 & -2.67 & -2.9 \\
\hline $17 \mathrm{X}-2,95-96$ & 154.65 & 21 & 20 & 1 & -2.25 & -2.53 \\
\hline $17 \mathrm{X}-2,100-101$ & 154.70 & 25 & 23 & 2 & -2.66 & -2.82 \\
\hline $17 \mathrm{X}-2,105-106$ & 154.75 & 23 & 20 & 3 & -3.08 & -3.47 \\
\hline $17 \mathrm{X}-2,110-111$ & 154.80 & 23 & 21 & 2 & -2.95 & -3.72 \\
\hline $17 X-2,115-116$ & 154.85 & 25 & 23 & 2 & -2.69 & -3.09 \\
\hline
\end{tabular}

Note: $*$ PDB bulk carbonate.

\section{Site 969}

Holes 969A and 969B were drilled on the Mediterranean Ridge, about $100 \mathrm{~km}$ south of the island of Crete, in water depths of $\sim 2200$ and $2202 \mathrm{~m}$, and recovered respectively 111.4 and $100.2 \mathrm{~m}$ of sediments.

The Miocene/Pliocene boundary was recognized at $102.8 \mathrm{mbsf}$ (Sample 160-969A-12H-1, $10 \mathrm{~cm}$ ) and $97.10 \mathrm{mbsf}$ (Sample 160969B-11H-6, $120 \mathrm{~cm}$ ). It corresponds to the sharp transition from structureless calcareous clays containing reworked calcareous nannofossils, non-age-diagnostic assemblages of late Miocene/early Pliocene, and bioturbated pale brown-gray nannofossil ooze with foraminifers characteristic of the early Pliocene MPL1 zone (Shipboard Scientific Party, 1996b). The first sapropel intercalation occurs from 100.32 to $100.12 \mathrm{mbsf}$ at Hole 969 A (i.e. $~ 1.5 \mathrm{~m}$ above the Miocene/ Pliocene boundary), whereas at Hole 969B it is composite with two intervals, the lower one beginning just at the onset of Pliocene from 97.10 to $97.00 \mathrm{mbsf}$ and the upper one from 96.60 to $96.40 \mathrm{mbsf}$. Despite the lack of biostratigraphic markers, the conformable nature of the sediments underlying the early Pliocene deposits suggest they belong to the uppermost Messinian; detailed correlation of the sequences from Holes 969A and 969B has proved difficult because of drilling disturbance and possible faulting in this region of intense deformation (Shipboard Scientific Party, 1996b).

In the two holes, the transition from Messinian to Pliocene is characterized by a sharp increase in the carbonate content of the sedi-
Table 3. Carbonate mineral composition and $\delta^{18} \mathrm{O}$ and $\delta^{13} \mathrm{C}$ values of the bulk carbonate fraction of the sediments at Hole 969B.

\begin{tabular}{|c|c|c|c|c|c|c|}
\hline $\begin{array}{l}\text { Core, section, } \\
\text { interval }(\mathrm{cm})\end{array}$ & $\begin{array}{l}\text { Depth } \\
\text { (mbsf) }\end{array}$ & $\begin{array}{c}\text { Total } \\
\text { Carbonates } \\
(w t \%)\end{array}$ & $\begin{array}{l}\text { Calcite } \\
(\mathrm{wt} \%)\end{array}$ & $\begin{array}{l}\text { Dolomite } \\
\text { (wt } \%)\end{array}$ & $\begin{array}{c}\delta^{18} \mathrm{O}^{*} \\
(\% \circ)\end{array}$ & $\begin{array}{l}\delta^{13} \mathrm{C}^{*} \\
(\% \circ)\end{array}$ \\
\hline \multicolumn{7}{|l|}{ 160-969B- } \\
\hline $11 \mathrm{H}-6,25-26$ & 96.15 & 65 & 62 & 3 & 1.33 & 0.97 \\
\hline $11 \mathrm{H}-6,30-31$ & 96.20 & 62 & 60 & 3 & 1.20 & 0.94 \\
\hline $11 \mathrm{H}-6,35-36$ & 96.25 & 66 & 63 & 3 & 1.25 & 0.99 \\
\hline $11 \mathrm{H}-6,40-41$ & 96.30 & 66 & 63 & 3 & 1.47 & 1.14 \\
\hline $11 \mathrm{H}-6,45-46$ & 96.35 & 74 & 72 & 2 & 1.34 & 1.07 \\
\hline $11 \mathrm{H}-6,50-51$ & 96.40 & 74 & 72 & 2 & 1.12 & 0.95 \\
\hline $11 \mathrm{H}-6,55-56$ & 96.45 & 80 & 79 & 1 & 0.80 & 0.45 \\
\hline $11 \mathrm{H}-6,60-61$ & 96.50 & 76 & 75 & 1 & 0.67 & 0.52 \\
\hline $11 \mathrm{H}-6,65-66$ & 96.55 & 69 & 67 & 2 & 0.19 & 0.37 \\
\hline $11 \mathrm{H}-6,70-71$ & 96.60 & 67 & 65 & 2 & 0.64 & 0.53 \\
\hline $11 \mathrm{H}-6,75-76$ & 96.65 & 78 & 76 & 2 & 1.13 & 1.22 \\
\hline $11 \mathrm{H}-6,80-81$ & 96.70 & 74 & 72 & 2 & 1.21 & 1.28 \\
\hline $11 \mathrm{H}-6,85-86$ & 96.75 & 70 & 67 & 3 & 1.08 & 1.01 \\
\hline $11 \mathrm{H}-6,90-91$ & 96.80 & 66 & 63 & 4 & 1.05 & 0.81 \\
\hline $11 \mathrm{H}-6,95-96$ & 96.85 & 63 & 60 & 3 & 0.91 & 0.80 \\
\hline $11 \mathrm{H}-6,100-101$ & 96.90 & 63 & 60 & 3 & 1.13 & 0.81 \\
\hline $11 \mathrm{H}-6,105-106$ & 96.95 & 64 & 61 & 3 & 0.74 & 0.46 \\
\hline $11 \mathrm{H}-6,110-111$ & 97.00 & 75 & 72 & 4 & 0.93 & 0.51 \\
\hline $11 \mathrm{H}-6,115-116$ & 97.05 & 71 & 68 & 3 & 0.71 & 0.11 \\
\hline $11 \mathrm{H}-6,120-121$ & 97.10 & 69 & 67 & 3 & 0.25 & -0.17 \\
\hline $11 \mathrm{H}-6,125-126$ & 97.15 & 20 & 14 & 5 & 0.36 & -0.47 \\
\hline $11 \mathrm{H}-6,130-131$ & 97.20 & 13 & 9 & 4 & 0.17 & -0.86 \\
\hline $11 \mathrm{H}-6,135-136$ & 97.25 & 14 & 8 & 6 & 0.54 & -0.96 \\
\hline $11 \mathrm{H}-6,140-141$ & 97.30 & 14 & 9 & 5 & 0.21 & -1.03 \\
\hline $11 \mathrm{H}-6,145-146$ & 97.35 & 13 & 8 & 5 & 0.20 & -1.05 \\
\hline $11 \mathrm{H}-6,149-150$ & 97.39 & 14 & 9 & 5 & 0.14 & -1.12 \\
\hline $11 \mathrm{H}-7,0-1$ & 97.40 & 13 & 8 & 5 & 0.33 & -1.02 \\
\hline $11 \mathrm{H}-7,5-6$ & 97.45 & 13 & 8 & 5 & 0.21 & -1.07 \\
\hline $11 \mathrm{H}-7,10-11$ & 97.50 & 15 & 9 & 5 & 0.18 & -1.06 \\
\hline $11 \mathrm{H}-7,15-16$ & 97.55 & 15 & 10 & 5 & 0.15 & -1.09 \\
\hline
\end{tabular}

Note: $*$ PDB bulk carbonate.

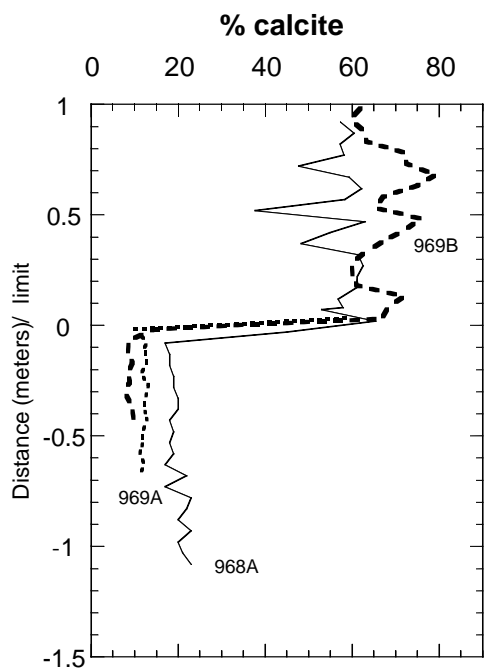

Figure 2. Variation with depth of the weight percent calcite content in the sediments above and below the Messinian/Pliocene boundary at Sites 968 and 969. The vertical scale corresponds to the relative distance in meters relative to this limit, which was located at $153.775 \mathrm{mbsf}$ at Hole $968 \mathrm{~A}$, at 102.825 mbsf at Hole 969A, and at 97.125 mbsf at Hole 969B, according to the change of the weight percent calcite content.

ments (see Fig. 2; Tables 2, 3). At Hole 969A, the average carbonate contents change abruptly from $18 \%$ in the Messinian to $62 \%$ in Sample 160-969A-12H-1, $10 \mathrm{~cm}$, which represents the lowermost Pliocene. This difference is caused by the increased calcite content from $12 \%$ to $58 \%$, whereas the dolomite fraction remains constant throughout the limit. The same distribution is observed in Hole 969B where the Messinian sediments display low carbonate contents 
( 14\%), except for the uppermost sample, which shows a slight increase up to $20 \%$, whereas the mean value reaches $70 \%$ in the early Pliocene. This difference also results from the increase of the calcite content from less than $10 \%$ in the Messinian to $\sim 67 \%$ in the early Pliocene. The dolomite content decreases slightly from $5 \%$ in the Messinian to $2.5 \%$ in the Pliocene. As in Hole 968A, dolomite (Pl. 1, Fig. 3) is considered as a detrital component.

The composition of the carbonate minerals is relatively homogeneous throughout the studied interval whatever their age; calcites are near stoichiometry $\left(3.033<\mathrm{d}_{104} \AA<3.035\right)$, whereas dolomites are calcium rich $\left(2.898<\mathrm{d}_{104} \AA<2.903\right)$.

The carbonate fraction of the Messinian sediments contains the same four main types of carbonate grains identified at Site 968 . The euhedral calcite crystals constitute the dominant phase, but the netting needle-like calcite and the coccoliths are still present in variable proportions (Pl. 1, Figs. 1-2).

Smear slides and SEM examinations indicate that the increase of calcite content in the Pliocene sediments results from the greater abundance of biogenic carbonates, especially the calcareous nannoplankton that is the main component of the sediment.

\section{Discussion}

The Messinian/Pliocene boundary is well recorded at ODP Sites 968 and 969 by an abrupt variation in lithology, total carbonate content, and carbonate mineralogy. Unfortunately, estimations of productivity fluxes, using the carbonate content as a possible proxy, seem rather difficult to establish because the sedimentation rate is unknown in the late Messinian. The low carbonate content of the Messinian sediments might result from the dilution by terrigenous components.

The dark-colored carbonate-poor nannofossil clays with brackish fauna characteristic of Messinian deposits are overlain by the early Pliocene light-colored carbonate-rich nannofossil clays with diversified assemblages of foraminifers. This sedimentological change records the major environmental change that occurred in the Mediterranean when the huge Paratethys fresh-water discharge stopped, and the marine waters reinvaded the whole basin.

\section{OXYGEN AND CARBON ISOTOPIC COMPOSITIONS OF THE CARBONATES}

The Messinian/Pliocene boundary appears similarly expressed at the two sites by significant $\delta^{18} \mathrm{O}$ and $\delta^{13} \mathrm{C}$ shifts from low to high values, but the amplitudes of the deviations are larger at Site 968 than at Site 969 (Figs. 3, 4).

\section{THE OXYGEN ISOTOPIC SIGNAL Results}

On the Eratosthenes Seamount (Hole 968A), the Messinian/ Pliocene boundary is marked by a shift of $\sim 4.5 \%$ of the $\delta^{18} \mathrm{O}$ values; it corresponds to the transition from $\delta^{18} \mathrm{O}$ values averaging -3\% , typical of brackish conditions at the end of Messinian, to $\delta^{18} \mathrm{O}$ values close to $1.5 \%$, characteristic of normal marine conditions at the onset of early Pliocene (Pierre and Rouchy, 1990).

On the Mediterranean Ridge, the $\delta^{18} \mathrm{O}$ change crossing the Messinian/Pliocene boundary appears relatively moderate (2\%o at Hole 969A and 1\%o at Hole 969B) and progressive, because the Messinian $\delta^{18} \mathrm{O}$ values are higher $(-0.8 \%$ o to $0.2 \%$ ), indicating a less important dilution by fresh waters than in the easternmost part of the Mediterranean.

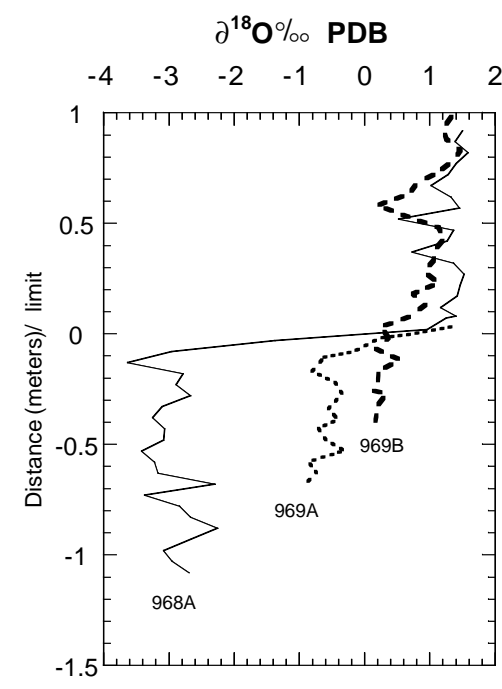

Figure 3. Variation with depth of the $\delta^{18} \mathrm{O}$ values of the bulk carbonate in the sediments above and below the Messinian/Pliocene boundary at Sites 968 and 969. The vertical scale corresponds to the relative distance in meters relative to this limit, which was located at $153.775 \mathrm{mbsf}$ at Hole $968 \mathrm{~A}$, at 102.825 mbsf at Hole 969A, and at 97.125 mbsf at Hole 969B, according to the change of the weight percent calcite content.

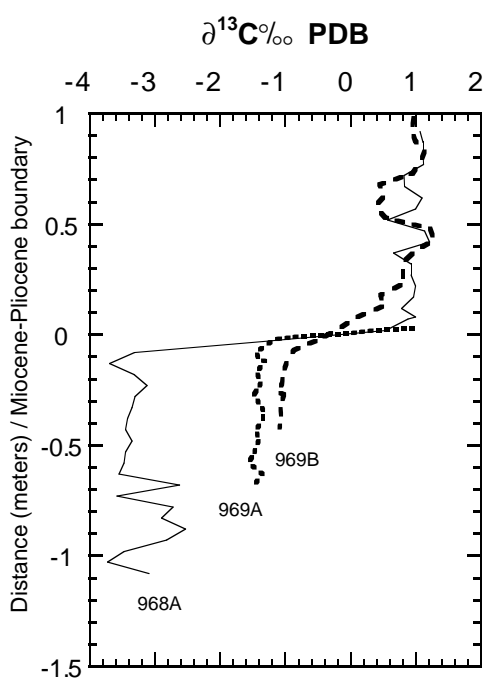

Figure 4. Variation with depth of the $\delta^{13} \mathrm{C}$ values of the bulk carbonate in the sediments above and below the Messinian/Pliocene boundary at Sites 968 and 969. The vertical scale corresponds to the relative distance in meters relative to this limit, which was located at $153.775 \mathrm{mbsf}$ at Hole 968A, at 102.825 mbsf at Hole 969A, and at 97.125 mbsf at Hole 969B, according to the change of the weight percent calcite content.

\section{Discussion}

The Messinian/Pliocene transition looks very rapid, because it takes place within a $10-\mathrm{cm}$ interval in both sites. In spite of the unknown sedimentation rate during the late Messinian, if it is assumed that it was at least equivalent (but more probably higher) to that of the early Pliocene, the duration for refilling the Mediterranean may be estimated to be comprised between 1000 and 2000 yr. Furthermore, this drastic environmental change at the onset of Pliocene appears 
synchronous and has the same duration at both Sites 968 and 969 of the Eastern Mediterranean, meaning that it is controlled by the abrupt entrance of Atlantic marine waters into the Mediterranean. The establishment of a large Atlantic/Mediterranean connection at this time was caused by a major extensional tectonic event in the Alboran Sea.

The dilution factor may be estimated by simple mass-balance calculations, taking that the oxygen isotope composition of the freshwater component was similar to the present-day average value $\left(\delta^{18} \mathrm{O}\right.$ $=-5 \%$ ) of the Mediterranean precipitations (Yurtsever, 1975) and that the oxygen isotope composition of the marine-water component was similar to the present-day Eastern Mediterranean surface waters $\left(\delta^{18} \mathrm{O}=+2 \%\right.$ ). This gives estimations of $65 \%, 30 \%$, and $15 \%$ for the fraction of fresh waters mixed with marine waters at Holes 986A, $969 \mathrm{~A}$, and 969B respectively, if it is assumed that the $\delta^{18} \mathrm{O}$ variations of carbonates are only related to the water $\delta^{18} \mathrm{O}$ changes, thus neglecting a temperature change during this period.

The early Pliocene sapropel layers at Hole 969B are marked by the drop of the $\delta^{18} \mathrm{O}$ values to $0.2 \%$, which indicates significant surface dilution by fresh waters. The duration of the stagnation events during which these sapropels were deposited may be estimated between 1200 and $2500 \mathrm{yr}$, using the thickness of the layers $(10-20 \mathrm{~cm})$ and the average sedimentation rates.

\section{THE CARBON ISOTOPIC SIGNAL Results}

The variations of the $\delta^{13} \mathrm{C}$ values parallel the $\delta^{18} \mathrm{O}$ variations. The $\delta^{13} \mathrm{C}$ values average $-3.5 \%$ at Hole $968 \mathrm{~A},-1.5 \%$ at Hole $969 \mathrm{~A}$, and $-1.0 \%$ at Hole $969 \mathrm{~B}$ in the Messinian, and $1.0 \%$ o at the three holes in the early Pliocene. The shift at the Messinian/Pliocene boundary reaches $4.5 \%$ on the Eratosthenes Seamount, but it ranges between $2.0 \%$ at Hole $969 \mathrm{~B}$ and $2.5 \%$ at Hole $969 \mathrm{~A}$ on the Mediterranean Ridge.

\section{Discussion}

The major hydrological change at the Messinian/Pliocene transition is thus well recorded by the $\delta^{13} \mathrm{C}$ values, which characterize the nutrient-rich waters of the late Messinian environment replaced by the well-ventilated marine waters in the early Pliocene. The source of ${ }^{13} \mathrm{C}$-depleted $\mathrm{CO}_{2}$ in the late Messinian waters may come either from deep nutrient inputs to the surface or from continental-water discharges. Both effects responsible for eutrophic conditions were probably acting when the circulation in the Mediterranean basins was severely restricted.

The early Pliocene sapropel layers at Hole 969B display low $\delta^{13} \mathrm{C}$ values that are indicative of increased nutrient inputs in the surficial waters.

\section{CONCLUSIONS}

The Messinian/Pliocene transition recovered on the northern flank of the Eratosthenes Seamount (Site 968) and on the Mediterranean Ridge south of Crete (Site 969) is characterized by sharp and synchronous discontinuities in lithology, mineralogy, and isotopic compositions that occur simultaneously, but with different amplitudes, at the two sites.

The late Messinian sediments are basically homogeneous nannofossil silty clays, with low carbonate contents. The low $\delta^{18} \mathrm{O}$ and $\delta^{13} \mathrm{C}$ values of the carbonate fraction are characteristic of brackish environments where eutrophic conditions prevailed because of restricted circulation and nutrient supplies by continental-water discharges. The hydric balance between marine and fresh waters was not homogeneous in the different parts of the Eastern Mediterranean that are now lying at similar depths (i.e., $2000-2200 \mathrm{~m}$ ). This indicates that these deep parts of the basin were only partly connected, because they were probably separated by a complex system of sills and straits. Furthermore, as in other deep parts of the Mediterranean during the terminal Messinian, the water depth had to be relatively shallow to explain the large and rapid changes of the hydric balance (Cita and Ryan, 1973; Pierre, 1982; Pierre and Fontes, 1978; Pierre and Rouchy, 1990).

By contrast, the early Pliocene sediments correspond to bioturbated nannofossil-rich clays, with high carbonate content. The positive $\delta^{18} \mathrm{O}$ and $\delta^{13} \mathrm{C}$ values of the carbonate fraction indicate that marine well-ventilated conditions were established in the entire Eastern Mediterranean Basin at this time.

This major hydrological change occurred very rapidly, so that the entire Mediterranean Sea was completely infilled by marine waters probably in $\sim 1000-2000 \mathrm{yr}$.

\section{ACKNOWLEDGMENTS}

This study received the financial support of the Institut National des Sciences de l'Univers of CNRS (INSU grant no. 963905 “Géosciences Marines").

\section{REFERENCES}

Cita, M.B., and Ryan, W.B.F., 1973. Timescale and general synthesis. In Ryan, W.B.F., Hsü, K.J., et al., Init. Repts. DSDP; 13: Washington (U.S. Govt. Printing Office), 1405-1416.

Cita, M.B., Wright, R.C., Ryan, W.B.F., and Longinelli, A., 1978. Messinian paleoenvironments. In Hsü K.J., Montadert, L., et al., Init. Repts. DSDP, 42 (Pt. 1): Washington (U.S. Govt. Printing Office), 1003-1035.

Craig, H., 1957. Isotopic standards for carbon and oxygen and correction factors for mass-spectrometric analysis of carbon dioxide. Geochim. Cosmochim. Acta, 12:133-149.

McCrea, J.M., 1950. On the isotopic chemistry of carbonates and a paleotemperature scale. J. Chem. Phys., 18:849-857.

Pierre, C., 1982. Teneurs en isotopes stables $\left({ }^{18} \mathrm{O},{ }^{2} \mathrm{H},{ }^{13} \mathrm{C},{ }^{34} \mathrm{~S}\right)$ et conditions de genèse des évaporites marines: application à quelques milieux actuels et au Messinien de Méditerranée [Doct. thesis]. Univ. Paris-Sud Orsay.

Pierre, C., and Fontes, J.C., 1978. Isotope composition of Messinian sediments from the Mediterranean sea as indicators of paleoenvironments and diagenesis. In Hsü, K.J., Montadert, L., et al., Init. Repts. DSDP, 42: Washington (U.S. Govt. Printing Office), 635-650.

Pierre, C., and Rouchy, J.M., 1990. Sedimentary and diagenetic evolution of Messinian evaporites in the Tyrrhenian Sea (ODP Leg 107, Sites 652, 653, and 654): petrographic, mineralogical, and stable isotope records. In Kastens, K.A., Mascle, J., et al., Proc. ODP, Sci. Results, 107: College Station, TX (Ocean Drilling Program), 187-210.

Rouchy, J.M., 1982. La genèse des évaporites messiniennes de Méditerranée. Mem. Mus. Nat. Hist. Nat., 50:1-267.

Shipboard Scientific Party, 1996a. Site 968. In Emeis, K.-C., Robertson, A.H.F., Richter, C., et al., Proc. ODP, Init. Repts., 160: College Station, TX (Ocean Drilling Program), 289-333.

, 1996b. Site 969. In Emeis, K.-C., Robertson, A.H.F., Richter, C., et al., Proc. ODP, Init. Repts., 160: College Station, TX (Ocean Drilling Program), 335-375.

Yurtsever, Y., 1975. Worldwide survey of stable isotopes in precipitation. Intern. Rep. IAEA.

Date of initial receipt: 15 January 1997

Date of acceptance: 30 June 1997

Ms 160SR-021 

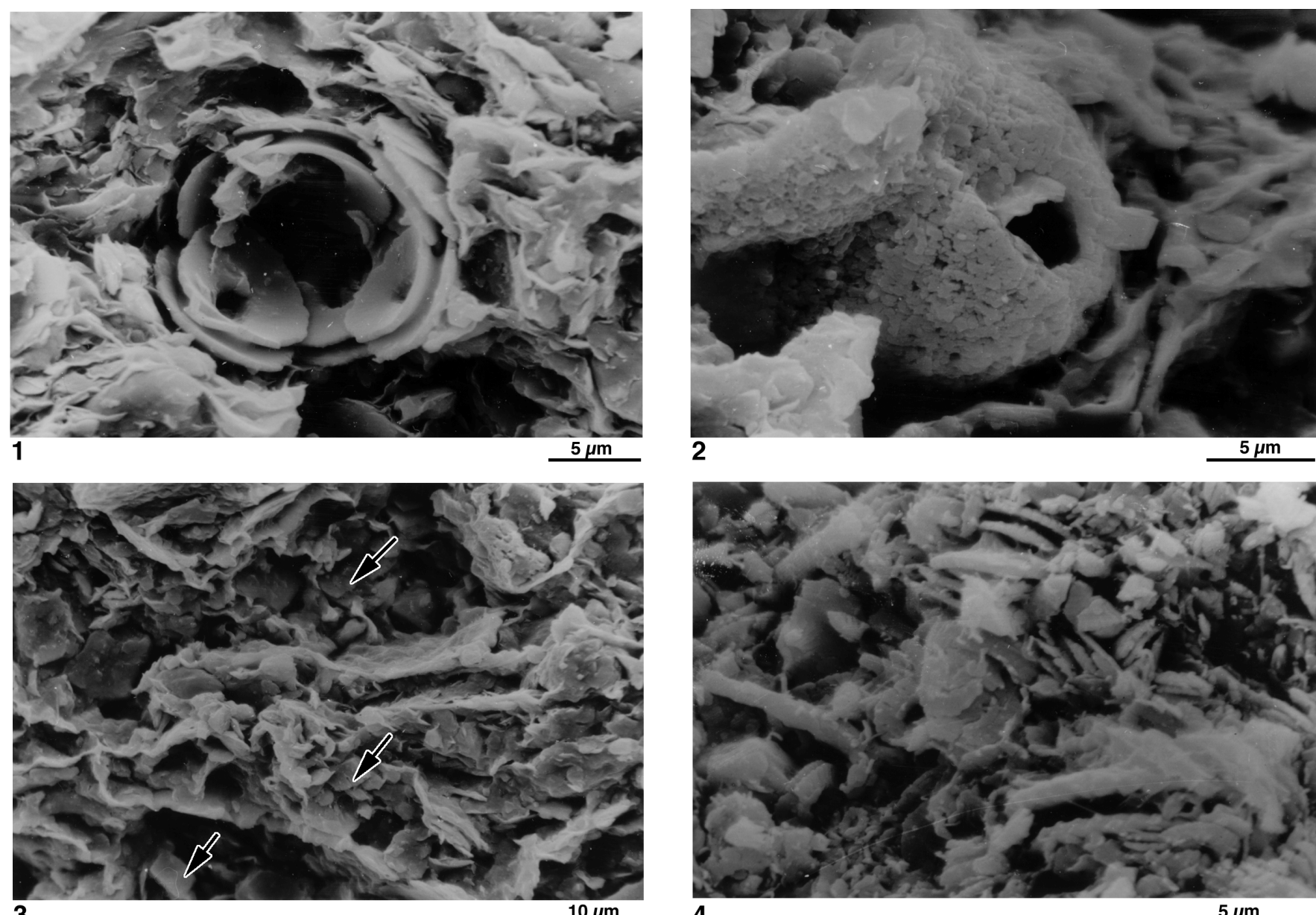

3

$10 \mu \mathrm{m}$

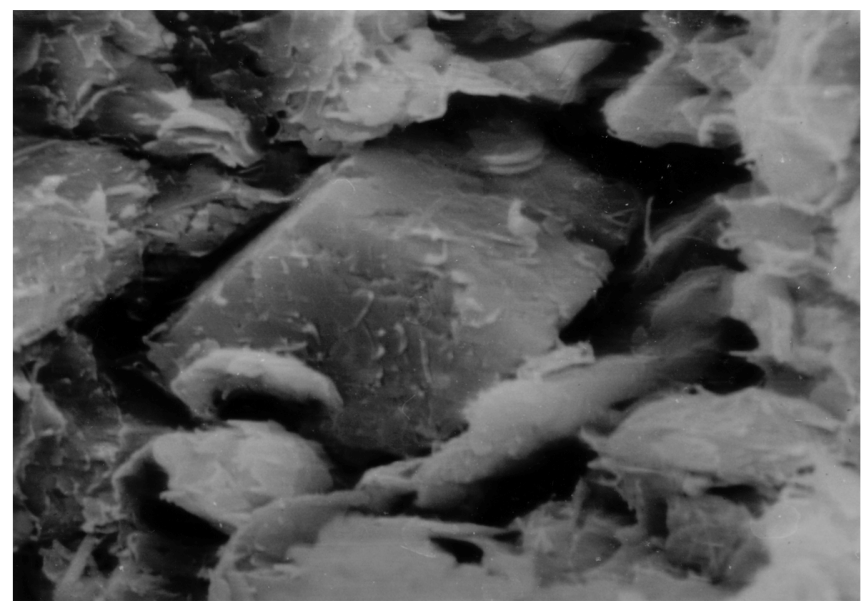

5

$5 \mu \mathrm{m}$

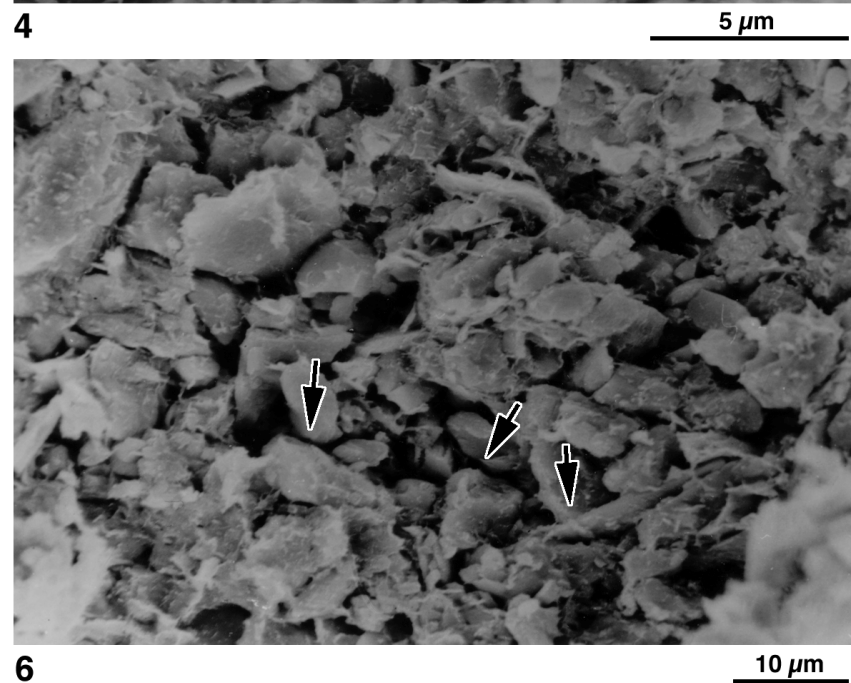

Plate 1. 1. Messinian sediments: SEM view of a coccosphere isolated within a sediment mostly composed of terrigenous elements and scarce subhedral carbonate grains. Sample 160-969B-11H-7, 10-11 cm. 2. Messinian sediments: SEM view of a fragment of Thoracospharea sp. within a terrigenous material. Sample 160-969B-11H-7, 10-11 cm. 3. Messinian sediments: SEM view of small dolomite (?) euhedral crystals (black arrows) associated with terrigenous components; a coccolith is visible in the right low corner. Sample 160-969B-11H-7, 10-11 cm. 4. Pliocene sediments: SEM view of sediment mostly composed of calcareous nannoplankton, associated with subhedral grains and various detrital fragments. Sample 160-968A-17X-1, 130-131 cm. 5. Messinian sediments: SEM view of euhedral grain of dolomite, associated with a coccolith. Sample 160-968A-17X-2, 20-21 cm. 6. Messinian sediments: SEM view of a sediment containing a great proportion of netting neddle-like grains of calcite (arrows) in a matrix made of terrigenous components. Sample 160-968A-17X-2, 20-21 cm. 